\title{
ORGANIC POLYCULTURE OF PASSION FRUIT, PINEAPPLE, CORN AND CASSAVA: THE INFLUENCE OF GREEN MANURE AND DISTANCE BETWEEN ESPALIERS
}

\author{
Policultivo orgânico de maracujá, abacaxi, milho e mandioca: \\ influência da adubação verde e distância entre espaldeiras
}

\author{
Sebastião Elviro de Araújo Neto ${ }^{1}$, Pedro Arruda Campos $^{2}$, Leonardo Barreto Tavella ${ }^{3}$, \\ Antônio Jussier da Silva Solino ${ }^{3}$, Irene Ferro da Silva ${ }^{3}$
}

\begin{abstract}
The organic fruit crop should incorporate the principles of sustainable agriculture, with a guarantee of productivity coupled with ecological diversity, using techniques of policultive with regional species. The aim of the study was to evaluate the effect of the green manure crops [Canavalia ensiformis (jack beans), Crotalaria spectabilis (sunn hemp), Pueraria phaseoloides (tropical kudzu), Arachis pintoi (peanut forage) and spontaneous plants] and distance between espaliers on the yields of Passiflora edulis f. flavicarpa (passion fruit), Ananas comosus (pineapple), Zea mays (maize), Manihot esculenta (cassava) and biomass in organic polyculture in the state of Acre, Brazil. The randomized block design experiment comprised plots encompassing the space between the rows of passion fruits (espaliers located $3 \mathrm{~m}$ or $4 \mathrm{~m}$ apart), and subplots that contained the green manure crops. Green biomass yield by jack beans, sunn hemp and tropical kudzu was greater than that provided by peanut forage and spontaneous plants. The polyculture of passion fruit, pineapple, maize and cassava presented a high overall yield (44462 $\left.\mathrm{kg} \mathrm{ha}^{-1}\right)$. The land-use efficiency of the polyculture system was between 2.45 (with sunn hemp) and 2.77 (with tropical kudzu) times greater than that achieved by individual monocultures. The yields of passion fruit (with tropical kudzu as cover crop) and pineapple (with spontaneous plants as green manure) were enhanced by some 72 and 34\%, respectively, when cultivated in plots comprising 3 m-spaced espaliers in comparison with plots containing $4 \mathrm{~m}$-spaced espaliers.
\end{abstract}

Index terms: Organic intercropping, cover crop, yield, land-use efficiency.

\section{RESUMO}

A fruticultura orgânica deve incorporar os princípios da agricultura sustentável, com garantia de produtividade aliado à diversidade ecológica, utilizando técnicas de cultivo consorciado com espécies regionais. Objetivou-se neste estudo avaliar o efeito de plantas de cobertura [Canavalia ensiformis (feijão-de-porco), Crotalaria spectabilis (crotalária), Pueraria phaseoloides (puerária), Arachis pintoi (amendoim forrageiro) e plantas espontâneas] e do espaçamento entre espaldeiras na produtividade de Passiflora edulis f. flavicarpa (maracujá amarelo), Ananas comosus (abacaxi), Zea mays L. (milho), Manihot esculenta (mandioca) e biomassa vegetal, em policultivo orgânico no estado do Acre, Brasil. O delineamento experimental foi de blocos ao acaso em esquema de parcelas compostas pelo espaçamento entre as espaldeiras do maracujá ( 3 e $4 \mathrm{~m}$ ) e subparcelas formadas pelas plantas de cobertura, com três repetições. Os solos cobertos com feijão-de-porco, crotalária e puerária produziram quantidades de biomassa vegetal superiores aos daqueles cobertos com amendoim forrageiro e plantas espontâneas. A produtividade geral do policultivo de maracujá, abacaxi, milho e cassava foi elevada (44462 $\mathrm{kg} \mathrm{ha}^{-1}$ ). O uso eficiente da terra no sistema de policultivo foi 2.45 (com crotalária) a 2.77 (puerária e plantas espontâneas) vezes superior ao do sistema de monocultivo. As produtividades do maracujá (em solo coberto com puerária) e abacaxi (em solo coberto com plantas espontâneas) aumentaram 72 e 34\%, respectivamente, nas parcelas em que o espaçamento entre espaldeiras era de $3 \mathrm{~m}$ em comparação com as parcelas em que o espaçamento era de $4 \mathrm{~m}$.

Termos para indexação: cultivo consorciado orgânico, plantas de cobertura, produtividade, uso eficiente da terra.

\section{INTRODUCTION}

The level of agricultural activity in the state of Acre remains relatively low in comparison with other regions of the Brazilian Amazon basin. While the production of Manihot esculenta (cassava), one of the major crops of the area, was 793017 tons in 2009-2010 with a yield of
21.0 tons ha ${ }^{-1}$, the yields of Zea mays (maize) and Ananas comosus (pineapple) were very much lower at just 96000 and 6843 tons year ${ }^{-1}$, respectively (AGRIANUAL, 2012). However, since around $88 \%$ of the state of Acre is covered with native forests, most of which are in protected natural areas, increasing crop productivity per unit area is of key importance in augmenting total productivity in the region.

\footnotetext{
${ }^{1}$ Universidade Federal do Acre/UFAC - BR 364 - Km 04 - 69920-200 - Rio Branco - AC - Brasil - selviro2000@yahoo.com.br

${ }^{2}$ Instituto de Defesa Animal e Fitossanitária do Acre/IDAF - Rio Branco - AC - Brasil

3Universidade Federal do Acre/UFAC - Rio Branco - AC - Brasil

Received in march 13, 2014 and approved in april 30, 2014
} 
In this context, improving crop cultivation techniques through the use of polyculture systems is considered an excellent option for increasing productivity per unit area, reducing the environmental impact caused by agriculture (Cecílio-Filho et al., 2011; Pypers et al., 2011; BezerraNeto et al., 2012) and augmenting the profitability of the farm (Bezerra-Neto et al., 2012).

In the state of Acre, the majority of farmers practice subsistence farming and either consume their own crops or exchange part of their production for other goods, a practice that guarantees survival, qualitative and quantitative seasonal food security and economic stability (Grisa, 2007). One method of increasing the abundance of farm products and improving the ecological diversity of the area would be to employ a policulture technique comprising common crops, such as maize, pineapple and cassava, together with a culture that is little exploited in the region. Passiflora edulis (passion fruit) would be an ideal candidate for inclusion in such a polyculture system since production in Acre is currently confined to just 17 dos 22 municipalities (IBGE, 2014), and cultivation is normally performed with minimal agricultural inputs (consumables and technology) resulting in an annual production of 403 tons with productivities of 7.6 tons ha ${ }^{-1}$ in conventional culture and 5.03 tons ha ${ }^{-1}$ in organic systems (Araújo-Neto et al., 2009). The average production costs of organically grown passion fruit vary between $\mathrm{R} \$ 0.64$ and $\mathrm{R} \$ 1.38$ $\mathrm{kg}^{-1}$, hence there is a significant requirement to increase the efficiency of yield and to reduce unit costs in order to improve profitability (Araújo-Neto et al., 2008).

An organic system comprising a polyculture of the type indicated above in association with green manure could progress crop farming in the region even further (Ferreira et al., 2011) as a result of the fixation of atmospheric nitrogen, the accumulation of $\mathrm{N}, \mathrm{P}$ and $\mathrm{K}$, and the consequent improvement in dry biomass production (Giacomini et al., 2003). Additional advantages of an organic polyculture system are: increased efficiency in the control of weeds in the main cultures (Silva, Hirata; Monquero, 2009), better particle aggregation with improved attenuation of fluctuations in soil temperature and humidity (Perin et al., 2002, 2004a; Loss et al., 2009), more efficient pest control, and the capacity to recycle biomass and nutrients (Bezerra; Oliveira; Vasconcelos, 2004; Sakonnakhon et al., 2006). Moreover, since passion fruit trees are typically cultivated in espalier form, increasing the spaces between the espaliers supporting the vines would permit facile co-cultivation with the other crops in the system. This practice should diminish production costs by reducing the demand for materials employed in the construction of the espaliers (Araújo-Neto et al., 2008) and augment productivity with less plants required per unit (Andrade-Júnior et al., 2003).

Within the Amazonian region, it is no longer environmentally acceptable to practice itinerant agriculture by deforestation and burning, but modern agriculture is fraught with difficulties associated with the timely distribution of agricultural consumables to the farms (Alves, 2008). In the present study, we have proposed an unconventional farming method comprising an organic polyculture of passion fruit, pineapple, maize and cassava with green manure, and we have evaluated the effects of different green manure crops and espalier spacings on crop yields.

\section{MATERIALS AND METHODS}

\section{Study area, polyculture and green manure}

The experiment was conducted at the Sítio Ecológico Seridó, Rio Branco, Acre, Brazil (953'16" $\mathrm{S}, 67^{\circ} 49^{\prime} 11^{\prime \prime} \mathrm{W}$; altitude $170 \mathrm{~m}$ ) during the period November 2009 to November 2011. According to the Köppen classification, the region presents a tropical moist climate $(\mathrm{Am})$ with a mean temperature of $24.5^{\circ} \mathrm{C}$, relative humidity of $84 \%$ and annual precipitation in the range 1700 to $2400 \mathrm{~mm}$. The soil is categorized as yellow clay with plinthite (argissolo amarelo alítico plíntico) according to the Brazilian Soil Classification System (EMBRAPA, 2006). Chemical analysis of horizon A (0 - 20 $\mathrm{cm})$ revealed the following characteristics: $\mathrm{pH}$ 5.4; base saturation 52.1\%; organic matter $18 \mathrm{~g} \mathrm{dm}^{-3} ; \mathrm{P} 7 \mathrm{mg} \mathrm{dm}^{-3}$; $\mathrm{K} 2.6 \mathrm{mmol}_{\mathrm{c}} \mathrm{dm}^{-3}$; $\mathrm{Ca} 27 \mathrm{mmol}_{\mathrm{c}} \mathrm{dm}^{-3} ; \mathrm{Mg}^{-3} 16 \mathrm{mmol}_{\mathrm{c}} \mathrm{dm}^{-3}$; Al $1 \mathrm{mmol}_{\mathrm{c}} \mathrm{dm}^{-3} ; \mathrm{H} 41 \mathrm{mmol}_{\mathrm{c}} \mathrm{dm}^{-3} ; \mathrm{Ca} / \mathrm{Mg} 1.68, \mathrm{Mg} / \mathrm{K}$ 6.15; Fe $530 \mathrm{mg} \mathrm{dm}^{-3}$; $\mathrm{Cu} 1.6 \mathrm{mg} \mathrm{dm}^{-3}$; Mn $99 \mathrm{mg} \mathrm{dm}^{-3}$; $\mathrm{Zn} 2.6 \mathrm{mg} \mathrm{dm}^{-3}$ and B $0.17 \mathrm{mg} \mathrm{dm}^{-3}$.

The plants used in the polyculture were: (i) P. edulis f. flavicarpa (yellow passion fruit) - cultivar composed of a mixture of seven selected genotypes from the germplasm bank of Universidade Federal do Acre, namely, progenies 2, 22, 23, 35, 37, 33 and 20 originating from Viçosa (MG, Brazil), Universidade Estadual do Norte Fluminense (Campos dos Goytacazes, RJ, Brazil), Porto Acre, Brasiléia and Rio Branco (AC, Brasil); (ii) Ananas comosus (L.) Merr. (pineapple) - cultivar Rio Branco-1; (iii) Zea mays L. (maize) - cultivar Bona Gold; (iv) Manihot esculenta Crantz (cassava) - cultivar BRS Caipora. The green manure crops were Canavalia ensiformis (L.) DC. (jack bean), Crotalaria spectabilis Roth (sunn hemp), Pueraria phaseoloides (Roxb.) Benth (tropical kudzu), Arachis pintoi (peanut forage) and spontaneous plants (control). 


\section{Experimental design}

The experiment was of a randomized complete block design comprising plots subdivided into subplots with three repetitions each. The plots encompassed the space between the rows of passion fruits (espaliers located $3 \mathrm{~m}$ or $4 \mathrm{~m}$ apart), while the subplots contained the green manure crops. Pineapple, maize and cassava were cultivated between the rows of passion fruit in all treatments. The experimental unit consisted of nine passion fruit vines distributed in three rows; the three vines placed at the central row were considered the applicable plot. The applicable plots for maize and cassava were defined as the areas of 6 $\mathrm{m}^{2}$ between the passion fruit rows, while the applicable plot for pineapple was defined as 20 plants plot ${ }^{-1}$.

\section{Soil tillage, weeding and cultivation}

The experimental area, which was previously covered with Brachiaria grass under a rotational management system, was ploughed and tilled to a depth of $20 \mathrm{~cm}$. Seeds of maize were then sown, with the aid of a dibber, in the prepared area in rows $1 \mathrm{~m}$ apart and at a density of 5 plants linear $\mathrm{m}^{-1}$. After emergence of the maize, trellises $(2 \mathrm{~m}$ high; 50 $\mathrm{m}$ long) comprising wooden espaliers connected by smooth wire were erected in rows 3 or $4 \mathrm{~m}$ apart with the purpose of training the passion fruit vines. The maize plantlets closest to each espalier and to each intended location of a passion fruit vine were then removed (one on either side) such that 42472 maize plants ha $^{-1}$ remained in plots with $3 \mathrm{~m}$-spaced espaliers and 44192 plants ha $^{-1}$ remained in those with 4 $\mathrm{m}$-spaced espaliers. In order to plant the passion fruit vines, pits ( $40 \times 40 \times 40 \mathrm{~cm} ; 3 \mathrm{~m}$ apart) were prepared and fertilized with a mixture of $12 \mathrm{~L}$ manure, $500 \mathrm{~g}$ dolomitic limestone and $200 \mathrm{~g}$ of phosphate. In November 2009, 70-day old passion fruit plants presenting first tendrils were transplanted to the experimental areas at final densities of 1111 plants ha $^{-1}$ in plots with $3 \mathrm{~m}$-spaced espaliers and of 833 plants ha $^{-1}$ in those with $4 \mathrm{~m}$-spaced espaliers.

When the maize plants had developed second leaves (stage V2), the crop was weeded with the aid of a horse drawn half-moon hoe at the rate of 0.74 man-days $\mathrm{ha}^{-1}$. Seven days after weeding the maize crop, pineapples were planted between the espaliers in rows spaced $0.4 \mathrm{~m}$ apart with $1.0 \mathrm{~m}$ between each plant in line. Three rows of pineapples were planted in plots with $3 \mathrm{~m}$-spaced espaliers to give a final density of 9300 plants ha ${ }^{-1}$, while plots with 4-m spaced espaliers were planted with four rows of pineapples to give a final density of 9200 plants ha $^{-1}$. Fifteen days after weeding the maize, the green manure crops were introduced into the subplots in an alternate arrangement
(Figure 1). Jack bean and sunn hemp were planted between the rows of the passion fruit and the rows of pineapple at final densities of 6420 and 9691 plants $^{-1} \mathrm{a}^{-1}$, respectively, with $3 \mathrm{~m}$-spaced espaliers, and at final densities of 6157 and 8704 plants ha $^{-1}$, respectively, with $4 \mathrm{~m}$-spaced espaliers. Tropical kudzu and peanut forage were planted in parallel rows at each side of the triple and quadruple pineapple rows at $0.30 \mathrm{~m}$ distance. Control plots were not planted with green manure crops although spontaneous plants were allowed to accumulate. Immediately after harvesting the maize, cassava was planted in two rows parallel to the pineapple rows at a density of 6200 plants ( $3 \mathrm{~m}$-spaced espaliers) and 4600 plants (4 m-spaced espaliers). Monocultures of passion fruit (1111 plants ha $\left.{ }^{-1}\right)$, maize (50000 plants ha $\left.{ }^{-1}\right)$, pineapple (20000 plants ha ${ }^{-1}$ ) and cassava (10000 plants ha ${ }^{-1}$ ) were established in an area adjacent to the organic polyculture using similar agricultural practices.

\section{Fertilization, weeding and pest control}

Culture management (pruning, weeding and fertilization) was conducted according to Brazilian legislation regarding organic crop production (Ministério da Agricultura, Pecuária e Abastecimento, 2011).

Fertilizer was applied to the passion fruit vines in February 2010 and 2011 in the form of $12 \mathrm{~L}$ of chicken manure enriched with $20 \mathrm{~kg} \mathrm{~m}^{-3}$ potassium sulfate and $3 \mathrm{~kg} \mathrm{~m}^{-3}$ boric acid. Passion fruit vines were allowed to grow as single vigorous stems up to $0.1 \mathrm{~m}$ above the wire, following which the stems were pruned. Secondary branches were arranged laterally up to $1.5 \mathrm{~m}$ each side and pruned to induce the formation of tertiary branches and these were arranged as before and pruned again to induce the formation of quaternary branches.

Selective manual weeding was performed eight times during the study period in order to remove all spontaneous plants leaving only the green crops. Pruning of peanut forage and tropical kudzu plants was performed five times, while sunn hemp plants were pruned twice until harvesting of the passion fruits in August 2011. Disease prevention and control was as follows: (i) anthracnose (Colletotrichum gloeosporioides) and mould (Cladosporium herbarum) - two applications of lime sulfur before and during the rainy season (the critical period), (ii) bugs (Diactor bilineatus), beetles (Diabrotica speciosa) and stem borers (Philonis passiflorae) - three scheduled applications of neem oil; and (iii) caterpillars (Dione juno juno and Agraulis vanillae vanillae) - application of Bacillus thuringiensis every 15 days during the rainy season. Pollination of passion fruit flowers was performed by natural pollinating species. 


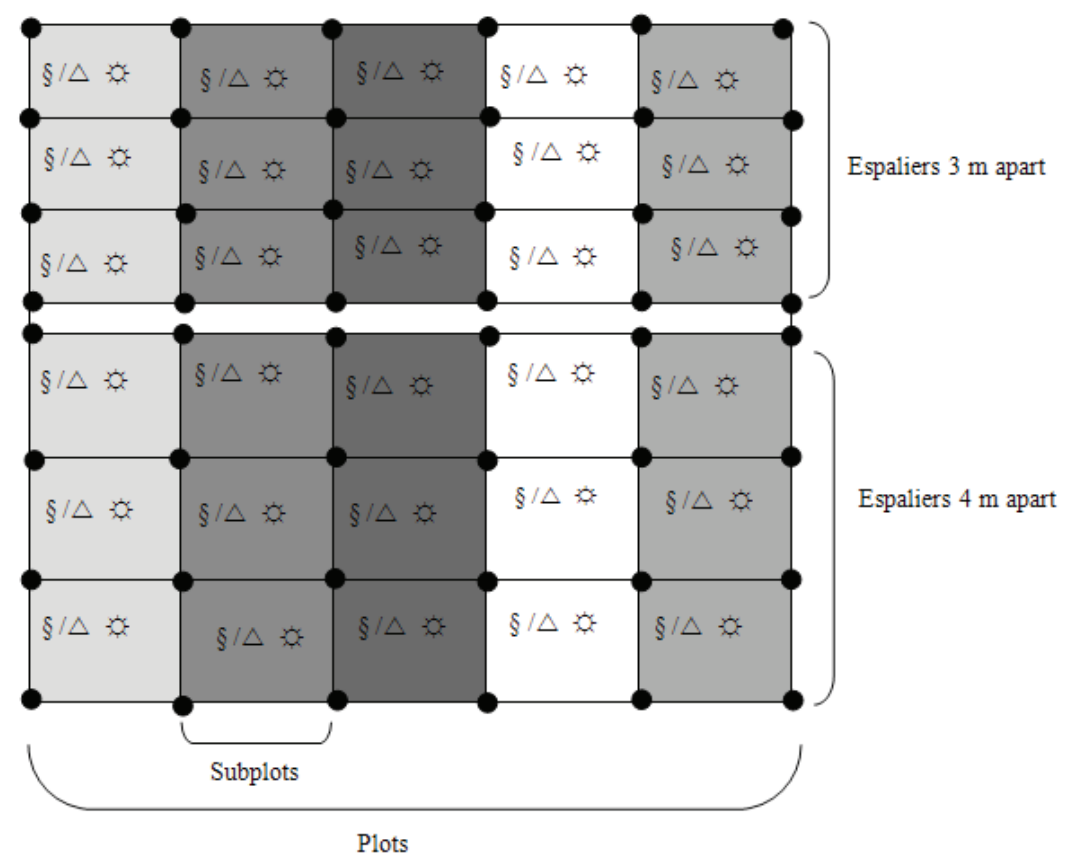

Figura 1 - Schematic representation of the organic polyculture of passion fruit (๑), pineapple ( cassava (r) with green manure crops feijão-de-porco $(\square)$, sunn hemp ( $\square$ ), tropical kudzu ( $\square)$, spontaneous plants $(\square$, control) or peanut forage ( $\square)$.

Parameters evaluated: Passion fruit yield was assessed as the product of the mean $(n=3)$ mass of fruit per plant $(\mathrm{kg})$ and the number of plants per hectare; pineapple yield was estimated as the product of the mean $(n=20)$ mass of a fruit $(\mathrm{kg})$ and the number of plants per hectare; maize and cassava yield were determined from the measured plot production expressed as a yield per hectare, but in the case of maize a correction of $13 \%$ was made to allow for humidity. Total plant biomass was estimated by weighing the residues (leaves, stems and flowers) from maize, cassava, green crops and spontaneous plants. Residues from maize and cassava were collected at harvesting time. Senescent leaves from cassava, passion fruit, sunn hemp and jack bean were gathered using collectors made of wood and netting $(0.50 \times 0.50 \mathrm{~m})$ placed below the aboveground portions, while those from tropical kudzu and peanut forage were collected manually from the same areas $(0.50 \times 0.50 \mathrm{~m})$ every 15 days. Prior to weeding, leaf samples from spontaneous plants were collected from a similar size area in order to quantify the biomass of this type of vegetation. All of the biomass material was dried in an oven at $65^{\circ} \mathrm{C}$ to constant weight.

Land-use efficiency was estimated by summation over all species of the quotients of polyculture productivity (commercial production; C) and monoculture productivity (M) calculated for each species individually according to:

Land-use efficiency $=\frac{\mathrm{C}_{\text {passion fruit }}}{\mathrm{M}_{\text {passion fruit }}}+\frac{\mathrm{C}_{\text {pineapple }}}{\mathrm{M}_{\text {pineapple }}}+\frac{\mathrm{C}_{\text {maize }}}{\mathrm{M}_{\text {maize }}}+\frac{\mathrm{C}_{\text {cassava }}}{\mathrm{M}_{\text {cassava }}}$

\section{Statistical analysis}

Data were submitted to tests for normality of the residues (Shapiro-Wilk test) and homogeneity of variances (Bartlett test), and $[\sqrt{ }(\mathrm{x}+2) / \log (\mathrm{x})]$ transformation was applied to results obtained for passion fruit productivity. The analysis of variance (ANOVA) F test was performed to detect significant differences $(P<0.05)$ among treatment means and, where appropriate, the Tukey test was applied to establish significant differences $(P<0.05)$ between mean values.

\section{RESULTS AND DISCUSSION}

None of the green manure crops produced significant alterations in the yields of passion fruit, pineapple or maize in comparison with the control (spontaneous plants), while the presence of sunn hemp (Fabaceae) had a negative effect on the yield of cassava (Table 1). Pypers et al. (2011) stated that intercropping of cassava with legume species 
generally improves soil fertility although, for species that produce large amounts of biomass, competition over prolonged periods can give rise to a decline in yield.

The mean yield of maize in the organic polyculture was $3255.9 \mathrm{~kg} \mathrm{ha}^{-1}$ (Table 1) and was not affected by any of the variables investigated, particularly by the green crops that were introduced immediately after weeding and the planting of pineapples. Heinrichs et al. (2005) also reported that, in the first year of cultivation, maize yield was not affected by intercropping with jack bean, pigeonpea (Cajanus cajan), dwarf mucuna (Mucuna deeringiana) or sunn hemp (Crotalaria spectabilis Roth). In the present study, although maize yield was higher than average for the state of Acre $\left(1993.10 \mathrm{~kg} \mathrm{ha}^{-1}\right.$ ) for the harvest season 2009/2010 (Agrianual, 2012), it was lower than the potential yield $\left(5700 \mathrm{~kg} \mathrm{ha}^{-1}\right)$. Factors that may have contributed to the reduced yield include the use of an open-pollinated rather than a hybrid cultivar, the lack of application of chemical fertilizers, and plant densities (42472 and 44192 plants $\mathrm{ha}^{-1}$ ) that were lower than the recommended rate (55000 plants ha ${ }^{-1}$ ). Following a study carried out under conditions of organic cultivation similar to those described herein, Echer et al. (2007) reported that, although maize yield was low $\left(2164 \mathrm{~kg} \mathrm{ha}^{-1}\right)$, the energetic benefits (energy input/output 4.49) and the cost of production $\left(\mathrm{R} \$ 0.63 \mathrm{~kg}^{-1}\right)$ were enhanced in comparison with conventional cultivation in which productivity is typically $6724 \mathrm{~kg} \mathrm{ha}^{-1}$, energy input/output is 1.71 and the cost of production is $\mathrm{R} \$ 0.73 \mathrm{~kg}^{-1}$. Indeed, low production costs and modest use of consumables (fertilizers and pesticides) are some of the principle advantages of organic agriculture.

The green crops jack bean, sunn hemp and tropical kudzu provided mean dry biomass $\left(24774.2 \mathrm{~kg} \mathrm{ha}^{-1}\right)$ that was $35.6 \%$ higher than that supplied by spontaneous plants $\left(18261.0 \mathrm{~kg} \mathrm{ha}^{-1}\right)$ and $13.2 \%$ higher than that of peanut forage (Table 1). The enhanced plant biomass can be explained by the botanical characteristics of these species and by the regular pruning performed on sunn hemp, tropical kudzu and peanut forage. In contrast, the spontaneous plants not only produced smaller amounts of biomass but they were also cleared periodically. Although spontaneous plants contribute to biodiversity and are important for the ecological control of agricultural pests and for nutrient cycling (Bezerra, Oliveira;Vasconcelos, 2004; Sakonnakhon et al., 2006), their capacity for biomass production is much lower in comparison with leguminous green crops such as Crotalaria juncea and Pennisetum glaucum (Silva, Hirata; Monquero, 2009), Avena strigosa Schieb (aveia preta), Vicia sativa L. (ervilhaca comum) and Raphanus sativus L. (nabo forrageiro) (Giacomini et al., 2003), all of which are extremely efficient in incorporating N, P and K into the soil.
The land-use efficiency (total yield per hectare) varied little with the type of green crop and ranged between 2.45 (sunn hemp) and 2.77 (tropical kudzu and spontaneous plants) (Table 1). The mean land-use efficiency for the polyculture was 2.65 , indicating that it would, require 2.65 ha of individual crops grown in a monoculture system to provide the same yield as 1 ha of the polyculture (Table 1). Moreover, the polyculture presented high yield (44462 $\mathrm{kg} \mathrm{ha}^{-1}$ ) and resulted in products that were suitable for home consumption (maize and cassava) and for trade (passion fruit and pineapple). According to Grisa (2007), the polyculture system not only guarantees that small farmers are self-sufficient in food (food security) but also allows farmers to sell products at market prices, thereby generating the income required to run the farm (consumables, services, etc) and for further investment (infrastructure, equipment, etc).

On this basis, the pessimistic scenario for small farmers of the Amazon region previously described by Alves (2008) could be transformed if farmers integrated polyculture and organic fertilization as well as supplementation with chemical fertilizers in the quantities allowed by Brazilian legislation (Ministério da Agricultura, Pecuária e Abastecimento, 2011). An organic polyculture system would ensure sustainable agriculture and high productivity per unit area, together with environmental preservation by promoting soil quality, temperature and humidity, and preventing the harmful consequences resulting from the excess use of chemical fertilizers, herbicides and pesticides (Perin, 2002; Perin et al., 2004b; Pyper, Verstraete; Merckx, 2005; Espindola et al., 2006; Sakonnakhon et al., 2006).

The effects of the interactions between green manure and the distance between the espaliers on the yields of passion fruit and pineapple are shown in table 2 . The yield of passion fruit in the area covered with tropical kudzu was $72.1 \%$ higher in plots comprising $3 \mathrm{~m}$-spaced espaliers (21677.2 $\left.\mathrm{kg} \mathrm{ha}^{-1}\right)$ compared with those containing 4 $\mathrm{m}$-spaced espaliers $\left(12597.1 \mathrm{~kg} \mathrm{ha}^{-1}\right)$. Since the distance between the passion fruit plants in each of the rows was 3 $m$ in all treatments, there was neither competition between the plants nor excess shading as observed in the experiment conducted by Andrade-Júnior et al. (2003).

However, there were 32 rows and 1111 plants in the plots comprising $3 \mathrm{~m}$-spaced espaliers compared with only 24 rows and 833 plants in the plots containing 4 $\mathrm{m}$-spaced espaliers. Thus, the overall amount of fertilizer applied to the plots comprising $3 \mathrm{~m}$-spaced espaliers was significantly greater and this contributed positively to the increased yield. 
Table 1 - Mean yield, plant biomass and land-use efficiency of the organic polyculture and monoculture systems described as a function of cover crop.

\begin{tabular}{|c|c|c|c|c|c|c|}
\hline \multirow{2}{*}{ Cultivation conditions } & \multicolumn{4}{|c|}{ Productivity $\left(\mathrm{kg} \mathrm{ha}^{-1}\right)$} & \multirow{2}{*}{$\begin{array}{c}\text { Plant } \\
\text { biomass } \\
\left(\mathrm{kg} \mathrm{ha}^{-1}\right)\end{array}$} & \multirow{2}{*}{$\begin{array}{l}\text { Land-use } \\
\text { efficiency }\end{array}$} \\
\hline & Passion fruit & Pineapple & Maize & Cassava & & \\
\hline \multicolumn{7}{|l|}{ Cover crop } \\
\hline Peanut forage & $17691.2 \mathrm{a}$ & $14639.9 \mathrm{a}$ & $2875.2 \mathrm{a}$ & $8216.7 \mathrm{ab}$ & $21885.8 \mathrm{ab}$ & $2.50 \mathrm{a}$ \\
\hline Sunn hemp & $17525.5 \mathrm{a}$ & $14798.0 \mathrm{a}$ & $3190.5 \mathrm{a}$ & $4348.9 b$ & $24011.1 \mathrm{a}$ & $2.45 \mathrm{a}$ \\
\hline Feijão-de-porco & $19964.5 \mathrm{a}$ & $14903.8 \mathrm{a}$ & $3350.6 \mathrm{a}$ & $7857.8 \mathrm{ab}$ & $25090.3 \mathrm{a}$ & $2.75 \mathrm{a}$ \\
\hline Tropical kudzu & $17137.1 \mathrm{a}$ & $13382.0 \mathrm{a}$ & $3371.8 \mathrm{a}$ & $12976.0 \mathrm{a}$ & $25221.3 \mathrm{a}$ & $2.77 \mathrm{a}$ \\
\hline Spontaneous plants & $18006.3 \mathrm{a}$ & $14069.2 \mathrm{a}$ & $3491.2 \mathrm{a}$ & $10513.9 \mathrm{a}$ & $18261.0 \mathrm{~b}$ & $2.77 \mathrm{a}$ \\
\hline Polyculture (mean) & 18064.9 & 14358.6 & 3255.9 & 8782.6 & - & 2.65 \\
\hline Monoculture & 20234.3 & 30564.0 & 3380.4 & 27230.8 & - & - \\
\hline Coefficient of variance in the plot $(\%)$ & 33.51 & 9.36 & 35.17 & 16.13 & 10.52 & 17.45 \\
\hline Coefficient of variance in the experiment (\%) & 19.82 & 12.3 & 16.9 & 34.2 & 12.89 & 10.07 \\
\hline
\end{tabular}

Within each column, mean values bearing the same letter are not significantly different according to the Tukey test $(\mathrm{P}>0.05)$.

Table 2 - Mean yields of passion fruit and pineapple in response to the interactions between green crops and distance between espaliers in a organic polyculture system.

\begin{tabular}{|c|c|c|c|c|c|}
\hline \multirow{2}{*}{$\begin{array}{l}\text { Distance between } \\
\text { espaliers }\end{array}$} & \multicolumn{5}{|c|}{ Yield $\left(\mathrm{kg} \mathrm{ha}^{-1}\right)$} \\
\hline & Peanut forage & Sunn hemp & Feijão-de-porco & $\begin{array}{l}\text { Tropical } \\
\text { kudzu }\end{array}$ & $\begin{array}{l}\text { Spontaneous } \\
\text { plants }\end{array}$ \\
\hline & \multicolumn{5}{|c|}{ Passion fruit } \\
\hline $3 \mathrm{~m}$ & $20979.8 \mathrm{Aa}$ & $20842.1 \mathrm{Aa}$ & $18910.9 \mathrm{Aa}$ & $21677.2 \mathrm{Aa}$ & $18762.0 \mathrm{Aa}$ \\
\hline $4 \mathrm{~m}$ & $14402.8 \mathrm{Aa}$ & $14208.9 \mathrm{Aa}$ & $21018.1 \mathrm{Aa}$ & 12597.1 Ba & $17250.7 \mathrm{Aa}$ \\
\hline \multicolumn{6}{|c|}{ Coefficient of variance in the plot $(\%)=33.15$} \\
\hline \multicolumn{6}{|c|}{ Coefficient of variance in the experiment $(\%)=19.82$} \\
\hline & & & Pineapple & & \\
\hline $3 \mathrm{~m}$ & $15370.4 \mathrm{Aa}$ & $15853.7 \mathrm{Aa}$ & 13408.4 Aa & $14453.3 \mathrm{Aa}$ & $16086.9 \mathrm{Aa}$ \\
\hline $4 \mathrm{~m}$ & 13909.3 Aa & $13742.3 \mathrm{Aa}$ & 16399.2 Aa & $12310.7 \mathrm{Aa}$ & $12051.5 \mathrm{Ba}$ \\
\hline \multicolumn{6}{|c|}{ Coefficient of variance in the plots $(\%)=9.36$} \\
\hline \multicolumn{6}{|c|}{ Coefficient of variance in the experiment $(\%)=12.37$} \\
\hline
\end{tabular}

The yield of passion fruit attained in the present study $\left(21677.2 \mathrm{~kg} \mathrm{ha}^{-1}\right)$ must be considered excellent in comparison with the average productivities achieved in Brazil $\left(14300 \mathrm{~kg} \mathrm{ha}^{-1}\right)$ and in the state of Acre $(7600 \mathrm{~kg}$ $\mathrm{ha}^{-1}$ ) through conventional cultivation (IBGE, 2011) and, more specifically, in Acre using an organic system with vertical espaliers (5030 $\mathrm{kg} \mathrm{ha}^{-1}$ ) (Araújo-Neto et al., 2009).
The factors that contributed to the increased yield achieved in the present study are the diversification and combination of crops, the early application and further supplementation of fertilizer, the provision of green biomass and the use of a passion fruit cultivar adapted to the region. Loss et al. (2009) reported that polyculture of passion fruit with Desmodium sp. as 
green manure crop increased the organic carbon in the soil aggregates to levels similar to those found in agroforestry systems.

The increase in passion fruit yield provided by tropical kudzu cover was probably influenced by the capacity of this legume to produce green biomass and to increase the nutrient content in the soil through nitrogen fixation (Espindola et al., 2006). In this context, Perin et al. (2004b) reported that soil covered with tropical kudzu accumulated $6600 \mathrm{~kg} \mathrm{ha}^{-1}$ of dry matter, $192 \mathrm{~kg}$ $\mathrm{ha}^{-1}$ of $\mathrm{N}, 13 \mathrm{~kg} \mathrm{ha}^{-1}$ of $\mathrm{P}$ and $75 \mathrm{~kg} \mathrm{ha}^{-1}$ of $\mathrm{K}$ within 12 months. Furthermore, the yield of banana trees cultivated in soil covered with tropical kudzu was much greater than in trees grown in a soil covered with spontaneous plants (Perin et al., 2009). It has also been reported that tropical kudzu improves particle aggregation, attenuates oscillations of temperature and humidity in the soil (Perin, 2002), and reduces Al exchange (Pypers; Verstraete; Merckx, 2005).

The although passion fruit yield tended to be higher in plots comprising $3 \mathrm{~m}$-spaced espaliers covered with peanut forage, sunn hemp and spontaneous plants, the differences in relation to plots containing $4 \mathrm{~m}$-spaced espaliers were not statistically significant (Table 2). The high coefficients of variation in the plots and in the experiment reported in table 2 probably arise from the natural variation that typically occurs in field experiments and from the large genetic variability of the passion fruit cultivar, which derives from seven genotypes from different Brazilian regions. Castro et al. (2011) also observed large variability among passion fruit vines grown in the Federal District (centre west region of Brazil).

Pineapple yield in plots comprising $3 \mathrm{~m}$-spaced espaliers covered with spontaneous plants was $33.5 \%$ higher than in equivalent plots containing $4 \mathrm{~m}$-spaced espaliers (Table 2). The main factors that contributed to the superior performance of plots with closer-spaced espaliers were the higher density of pineapples (100 plants $\mathrm{ha}^{-1}$ more) and the larger quantity of fertilizer applied. Plants, such as the pineapple, that fix carbon through the crassulacean acid metabolism route are less productive than species with $\mathrm{C} 3$ and $\mathrm{C} 4$ metabolic pathways since incorporation of $\mathrm{CO}_{2}$ into photosynthetic products is much smaller (Vieira et al., 2010). Although pineapple is sturdy and well adapted to the tropics, the yield can be considerably enhanced by facilitating the incorporation of fertilizers and water, and through the regular control of weeds (Cunh; Cabral; Souza, 1999).

\section{CONCLUSIONS}

An organic polyculture system comprising passion fruit, pineapple, maize and cassava represents a viable proposition in the Amazon region as demonstrated by an average land-use efficiency of 2.65 , which was independent of the type of green manure crop employed. Green biomass yield by jack beans, sunn hemp and tropical kudzu was greater than that provided by peanut forage and spontaneous plants. Cassava yield was reduced significantly in the presence of sunn hemp as cover crop. The productivities of passion fruit (with tropical kudzu as cover crop) and pineapple (with spontaneous plants as green manure) were enhanced by some 72 and $34 \%$, respectively, through cultivation in plots comprising $3 \mathrm{~m}$-spaced espaliers in comparison with plots containing $4 \mathrm{~m}$-spaced espaliers.

\section{REFERENCES}

AGRIANUAL - Anuário da Agricultura Brasileira. Produção de Frutas no Brasil. São Paulo: FNP Consultoria, 2012.

ALVES, E. Agricultura itinerante ou moderna na região Amazônica? Revista de Política Agrícola. 17(2):3-4, 2008.

ANDRADE-JUNIOR, V. C. et al. Produção de maracujazeiro-amarelo sob diferentes densidades de plantio. Pesquisa Agropecuária Brasileira. 38(12):1381-1386, 2003.

ARAÚJO-NETO, S. E. et al. Rentabilidade econômica do maracujazeiro-amarelo plantado em covas e em plantio direto sob manejo orgânico. Revista Brasileira de Fruticultura. 30(4):940-945, 2008.

Produtividade e vigor do maracujazeiroamarelo plantado em covas e plantio direto sob manejo orgânico. Ciência Rural. 39(3): 678-683, 2009.

BEZERRA, M. S.; OLIVEIRA, M. R. V.; VASCONCELOS, S. D. Does the presence of weeds affect Bemisia tabaci (Gennadius) (Hemiptera: Aleyrodidae) infestation on tomato plants in a semi-arid agro-ecosystem? Neotropical Entomology. 33(6):769$775,2004$.

BEZERRA-NETO, F. et al. Assessment of agroeconomic indices in polycultures of lettuce, rocket and carrot through uni- and multivariate approaches in semi-arid Brazil. Ecological Indicators. 14(1):11-17, 2012. 
CASTRO, A. P. G. et al. Genetic variability of Passiflora spp. from commercial fields in the Federal District, Brazil. Ciência Rural. 41(6):996-1002, 2011.

CECÍLIO-FILHO, A. B. et al. Agronomic efficiency of intercropping tomato and lettuce. Anais da Academia Brasileira de Ciências. 83(3):1109-1119, 2011.

CUNHA, G. A. P.; CABRAL, J. R. S.; SOUZA, L. F. S. O Abacaxizeiro. Cultivo, Agroindústria e Economia. Brasília: Embrapa Comunicação para Transferência de Tecnologia, 1999.

ECHER, F. R. et al. Avaliação da eficiência energética e econômica em sistemas de produção de milho (Zea mays L.) sob manejo de base ecológica e convencional. Revista Brasileira de Agroecologia. 2(2):974-977, 2007.

ESPINDOLA, J. A. A. et al. Bananeiras consorciadas com leguminosas herbáceas perenes utilizadas como coberturas vivas. Pesquisa Agropecuária Brasileira. 41(3):415-420, 2006.

\section{EMPRESA BRASILEIRA DE PESQUISA}

AGROPECUÁRIA. Centro Nacional de Pesquisa do Solo. Sistema brasileiro de classificação de solos. (2. Ed.) Brasília: Embrapa, 2006. 412 p.

FERREIRA, R. L. F. et al. Produção orgânica de rabanete em plantio direto sobre cobertura morta e viva. Horticultura Brasileira. 29(3):299-303, 2011.

GIACOMINI, S. J. et al. Matéria seca, relação C/N e acúmulo de nitrogênio, fósforo e potássio em misturas de plantas de cobertura de solo. Revista Brasileira de Ciências do Solo. 27(2):325-334, 2003.

GRISA, C. Para além da alimentação: papeis e significado da produção para autoconsumo na agricultura familiar. Revista Extensão Rural. 14(1):1354, 2007.

HEINRICHS, R. et al. Características químicas de solo e rendimento de fitomassa de adubos verdes e de grãos de milho, decorrente do cultivo consorciado.

Revista Brasileira de Ciência do Solo. 29(1):71-79, 2005.
INSTITUTO BRASILEIRO DE GEOGRAFIA E ESTATÍSTICA. Produção Agrícola Municipal. Brasília: Sistema IBGE de Recuperação Automática, 2014. Available at: < http://www.ibge.gov.br/home/ estatistica/economia/pam/2010/default.shtm $>$ Accessed on February 5, 2011.

\section{INSTITUTO BRASILEIRO DE GEOGRAFIA E} ESTATÍSTICA. Produção Agrícola Municipal. Brasília: Sistema IBGE de Recuperação Automática, 2014. Available at: < http://www.ibge.gov.br/home/ estatistica/economia/pam/2012/default.shtm $>$ Accessed on $10^{\text {th }}$ April 2014.

LOSS, A. et al. Distribuição dos agregados e carbono orgânico influenciados por manejos agroecológicos.

Acta Scientarum. Agronomy. 31(3):523-528, 2009.

MINISTÉRIO DA AGRICULTURA, PECUÁRIA E ABASTECIMENTO. Instrução normativa No. 46, de 06 de outubro de 2011. Aprova o Regulamento Técnico para os Sistemas Orgânicos de Produção Animal e Vegetal, constante do Anexo I à presente Instrução Normativa. Brasília: MAPA, 2011. Available at: $<<w w w$. agricultura.gov.br $>$ Accessed on $10^{\text {th }}$ April 2014.

PERIN, A. et al. Efeito da cobertura viva com leguminosas herbáceas perenes na agregação de um argissolo. Revista Brasileira de Ciências do Solo. 26(3):713-720, 2002.

. Efeitos de coberturas vivas com leguminosas herbáceas perenes sobre a umidade e temperatura do solo. Revista Agronomia. 38(1):27-31, 2004a.

. Cobertura do solo e estoque de nutrientes de duas leguminosas perenes, considerando espaçamentos e densidades de plantio. Revista Brasileira de Ciências do Solo. 28(2):207-213, 2004 b.

Desempenho de bananeiras consorciadas com leguminosas herbáceas perenes. Ciência e Agrotecnologia. 33(6):210-217, 2009.

PYPERS, P.; VERSTRAETE, S.; THI, C. P.; MERCKX, $R$. Changes in mineral nitrogen, phosphorus availability and salt-extractable aluminium following the application of green manure residues in two weathered soils of South Vietnam. Soil Biology \& Biochemistry. 37(1):163-172, 2005. 
PYPERS, P. et al. Increased productivity through integrated soil fertility management in cassava-legume intercropping systems in the highlands of Sud-Kivu, DR Congo. Field Crops Research. 120(1):76-85, 2011.

SAKONNAKHON, S. P. N. et al. Weeds - friend or foe? The role of weed composition on stover nutrient recycling efficiency. Field Crops Research. 97(23):238-247, 2006.
SILVA, A. C.; HIRATA, E. K.; MONQUERO, P. A. Produção de palha e supressão de plantas daninhas por plantas de cobertura, no plantio direto do tomateiro. Pesquisa Agropecuária Brasileira. 44(1):22-28, 2009.

VIEIRA, D. A. P. et al. Fluorescência e teores de clorofilas em abacaxizeiro cv. pérola submetido a diferentes concentrações de sulfato de amônio. Revista Brasileira de Fruticultura. 32(2):360-368, 2010. 